LECH MIODYŃSKI

(10) HTTP://ORCID.ORG/ 0000-0003-2053-2277

Uniwersytet Śląski w Katowicach

e-mail: lemi8@wp.pl

\title{
Genotypy macedońskiej tradycji jako czynniki tekstotwórcze
}

\author{
Abstract \\ Genomes of the MacedonianTradition as Text-Creating Factors
}

This article presents the key currents of the historical, cultural and literary traditions moulded in the collective consciousness of the Macedonians and designed for being inspiration and ideological background for the various kinds of the native texts from the beginning of $19^{\text {th }}$ century. Mechanics of the using of the essential component parts of diverse traditions in a chronological order were depicted, with the special taking into consideration the nation-creating motivations and the potential of the building of strong autonomous identity through their particular types (for instance - ancient, folk, Mediterranean, biblical, revolutionary-liberation and other). As a common aims of the strategy of the creative exploiting of their indications in various periods (especially in literary works) were regarded: confirmation of the collective lineage, proving cultural and political independence on the diachronic level and creation of the coherent canon of the national values in the situation of threat to the ethnic and territorial-state integrity.

Keywords: Macedonian literature, cultural history, tradition, canon, collective identity

Słowa kluczowe: literatura macedońska, historia kultury, tradycja, kanon, tożsamość zbiorowa

W szeroko pojętym piśmiennictwie macedońskiego obszaru etnicznego od końca XVIII stulecia - zatem jeszcze na długo przed ukonstytuowaniem się stricte narodowej świadomości jego twórców oraz kodyfikacją języka literackiego w roku 1945 - powstały specyficzne postacie autorskich identyfikacji z elementami wspólnego kodu kulturowego i historycznego imaginarium uważanego za rodzime. Ich sukcesja jako form normatywnych bądź (znacznie rzadziej) negatywnych wzorców dookreśliła się przy tym w wymiarach ikoniczno-symbolicznym, narracyjnym i mitotwórczym, przyczyniając się do stworzenia schematycznego protoobrazu tożsamości budującego kanon wartości historycznych, religijnych, kulturowych czy literackich przypisanych do narodu już w warunkach niepod- 
ległości państwowej - uzyskanej przezeń dopiero w ostatniej dekadzie minionego tysiąclecia. W związku z wymuszeniem tu przez warunki historyczne mechanizmu ewolucji nietypowej obserwowanej na wielu poziomach (a ujmowanej najczęściej przez kulturo- i literaturoznawców oraz dziejopisarzy i politologów w kategoriach rozwoju achronologicznego, nieciągłości czy hybrydyczności, relatywizacji lokalnych tożsamości i ahistorycznej kumulacji zjawisk) długo nie mogła się utrwalić tendencja do wyłącznie wewnątrznarodowego hierarchizowania fenomenów kulturowych bądź literackich (na przykład jasnej kwalifikacji do wysokiego bądź niskiego obiegu komunikacyjnego lub autokrytycznego wartościowania mniej cennych tekstów), za to na długo zadomowiły się działania selekcjonujące i separujące całokształt własnej tradycji od sąsiednich - greckiej, bułgarskiej i serbskiej.

Natężenie tej aktywności zależało od kierunków politycznego separatyzmu lub integralizmu i stosownie do nich kreowało również zmienne określenia etnonimiczne samego narodu. $Z$ tej przyczyny, podobnie jak za sprawą ambiwalentnego stosunku do wcześniej skodyfikowanych narodowych kultur postosmańskiego Półwyspu Bałkańskiego, nie mogła też dojrzeć rzetelna dyskusja o czynnikach obcych i faktycznie rodzimych w miejscowym uniwersum kulturowym, w szczególności w obliczu istniejącego macedońskiego synkretyzmu religijnego, nawarstwień językowych czy uproszczonych typologizacji historycznoliterackich. Precyzję wartościujących ocen własnego dziedzictwa musiały z konieczności zastąpić kierowane na zewnątrz wypowiedzi konfrontacyjno-polemiczne pisane w poetyce „katalogów różnic”, jakich wiele zresztą w bałkańskich środowiskach powstawało z ambicji podkreślenia rozmaitych ekskluzywizmów etnogenetycznych, etnograficzno-mitologicznych czy lingwistycznych. Różne segmenty periodyzacji narodowego procesu emancypacyjnego wzmacniano poza tym bądź łączono funkcjonalnymi ,protezami tradycji” mającymi w sposób kamuflujący uporządkować materiał historyczny w zgodzie ze standardami terminologicznymi i periodyzacjami kultury i literatury powszechnej, czego pierwociny wiążą się z odpornym na wiedzę naukową mitotwórstwem większości słowiańskich romantyków. U schyłku XX wieku ich odbicie zyska wszak dodatkowe, wzmocnione nowoczesnym słownikiem pojęć walory apologetyczne i perswazyjne (Macedonia jako etnograficzno-folklorystyczny relikt europejski, prawo wyłączności do tradycji głagolickiej, nobilitacja trwałych archaizmów w kulturze materialnej [podczas gdy formy niematerialne często ewoluowały], antykizacja genezy ludowych obrzędów, „ciągłość nietypowa” literatury z ,etapem folkloru” itp.).

Tezę o fazowej powtarzalności (przez ponad dwieście lat) odwołań do tych samych genotypów, składników eklektycznej tradycji - mimo że wiele z nich nauka zdążyła w międzyczasie zweryfikować negatywnie jako „cywilizacyjne implanty" w południowosłowiańskim świecie - potwierdza choćby współczesne przejmowanie czy też odnawianie pochodzącego z okresu dziewiętnastowiecznego odrodzenia kulturalnego dualizmu w łonie prymarnego prototekstu macedońskiej kultury: obejmującego mianowicie substrat ludowy/ustny (w warstwie słownej liryczno-epicki, sięgający średniowiecznych korzeni) oraz z drugiej strony zinstrumentalizowany w zdeformowanych często tekstach wyjściowych, wieloźródłowy 
i genetycznie nierodzimy antyczny, którego starożytne współrzędne i uniwersalna w kontekście europejskiej cywilizacji treść zostały słowiańskiej wspólnocie przybyszów przekazane jako należny jej „testament terytorialny”. Wykorzystanie składnika pierwszego, akcentujące paradygmat ludowy z reguły przywołuje aspekt tradycji w rozumieniu przedmiotowym (jako konkretne elementy wiary, obyczaju czy języka - co widoczne jest już w nielicznych utworach oświeceniowych eksponujących nadrzędną wobec tych komponentów etyczną stronę chrześcijaństwa), oznaczając zazwyczaj same te obiekty obecne w międzypokoleniowej relacji. O wiek później w oficjalnej wersji - okrojonej do kultu zdesakralizowanych często artefaktów średniowiecznych, urzędowego folkloryzmu i matrycy „wyzwoleńczej” (antytureckiej i antyfaszystowskiej) - przetworzone zostanie ono w „dyskurs tradycji” w federacyjnej Jugosławii. Syntetyczny zaś konstrukt drugi (zasymilowanego antyku), w istocie radykalnie zaprogramowana ,tradycja wynaleziona", w czasach późnoromantycznych zyska znamię nie tyle materiałowe, ile procesualne (ciągłego aktualizowania i twórczego dopowiadania odkrywanych treści), co stanie się także domeną prac pseudonaukowych i licznych wypowiedzi artystycznych po roku 1991. Wielokrotne posłużenie się przez pochodzących z różnych okresów autorów tekstów literackich i nieliterackich definicją oraz uzasadnieniem ważności kategorii tradycji staje się zatem pierwszorzędną strategią konstytuującą narodową ideę integracyjną w warunkach niestabilności politycznej, terytorialnej i językowej (nierzadko przybierającej kształt całkowitej negacji macedońskiego bytu). Oba wymienione sposoby kreowania aktów ,terapeutycznej retrospekcji" mogą w takiej perspektywie uwzględniać różnorodne przydatne inspiracje ideowe: herderowską wizję ludu, nobilitację ustnego przekazu - podpory zbiorowej pamięci, heroizację ideału człowieka antycznego czy prawosławny kult Ojców i Nauczycieli ${ }^{1}$. Najczęściej wszak w rzeczywistości tekstowej były one wyzyskiwane jedynie jako odzwierciedlenia konkretnych obrazów osób oraz wydarzeń w świadomości potocznej i przedstawiane w manierze dydaktycznej prezentacji, gdyż taką wizualizację i konwencję językową zakładała utylitarna orientacja owych znacznie szerszych niż narodowe koncepcji.

W religijnym wariancie tutejszego oświecenia wartości tradycyjne widziano przez pryzmat teologiczny uwypuklający aktualizację treści objawienia przechowywanych w pamięci zbiorowej, lecz już z widocznym pierwiastkiem ich adaptacji do aktualnych warunków społecznych. Zgodnie z jej wymaganiami Joakim Krčovski podkreślał na przykład znaczenie przystępności sakralnego języka dla pospolitego odbiorcy, a obecne w twórczości Kirila Pejčinovicia odniesienia do religijnej genealogii prawosławnego ludu w celu utwierdzenia w nim ładu moralnego pełniły funkcję identyfikującą dziedzictwo etnosu z pożytecznymi w praktyce przesłaniami tekstu biblijnego. Intencją takiej postawy było rzecz jasna powstrzymanie dechrystianizacji (zagrażającej zbiorowości choćby poprzez zwyczaje składania kurbanu czy rozpowszechnienie amuletów jako ty-

${ }^{1}$ W ostatnim przypadku wyznaczniki tradycji ilustruje czytelny fragment współczesnego wiersza: „Piśmiennictwo / Święci / Święte księgi / Nauczyciele / Uczniowie / Mądrość / Mędrcy / Monastery / Szkoły”. П. Башевски, Коренот нам, Маглите на Кајмакчалан, Скопје 1995, стр. 44 (wszystkie tłumaczenia cytatów w języku macedońskim - L.M.). 
powe zewnętrzne naleciałości muzułmańskie), u Pejčinovicia jednak dochodziła do tego fundamentalna krytyka wszelkich przesądów - co wiązało autora nie tylko z jego greckim protoplastą Iliasem Miniatisem, lecz również z prekursorami oświecenia zachodniego. Idealizacja przeszłości w wariancie półlegendarnym, przy zastąpieniu sygnatur „rodzimej” wiary argumentami mądrości zbiorowej (czyli zakumulowanej głównie w folklorze wiedzy o tradycji) i zdroworozsądkowym podejściem do kwestii etycznych, stanowiła zaś znak rozpoznawczy jedynego przedstawiciela świeckiej wersji myśli oświeceniowej Jordana Hadžikonstantinova-Džinota, dla którego pozbawieni ogłady i niewykształceni rodacy powinni przynajmniej „uświadomić sobie własne dawne pochodzenie" ${ }^{2}$. Z kolei pierwsi krzewiciele idei wczesnoromantycznego „słowiańskiego odrodzenia” (poeta i twórca macedońskiej folklorystyki Konstantin Miladinov ukuł na jego określenie termin новородствение) poszukiwali źródeł niehelleńskiej przede wszystkim rodzimości jeszcze głębiej w wyróżnikach wspólnoty etnograficzno-językowej - nierzadko przyjmując politycznie korzystną szerszą denominację bułgarskości, lecz zarazem nie umiejąc jeszcze dokonać w obrębie tej wspólnoty ścisłych i innych niż regionalne rozróżnień pojęciowych. Miladinov za główny przedmiot transmisji w obrębie tradycji uznał ludowe pieśni z ich afirmacją dawnych wielkich czynów ${ }^{3}$, podczas gdy niemal w tym samym czasie Rajko Žinzifov - szerzej widziane dziedzictwo pokoleń obejmujące ,język, narodowość, wiarę, obyczaje"4.

Tego rodzaju uniwersalność i płynna semantyka motywu „rodzimych korzeni" z czasem stawała się coraz mniej adekwatna do wielonarodowej rzeczywistości kraju, w którym z przyczyn politycznych za wszelką cenę usiłowano stworzyć jakąś przekrojowo-regionalną tożsamość tradycji wspólnej dla „wszystkich mieszkańców Macedonii”, a jednocześnie wydzielić z niej i na pierwszy plan wysunąć protonarodową - związaną z populacją słowiańsko-prawosławną, lecz jeszcze pozbawioną nowoczesnego skodyfikowanego języka. $Z$ tej przyczyny, przy wciąż niedookreślonym kryterium etnojęzykowym, odwoływano się do znaczeń geograficznych, wyznaniowo-eklezjologicznych czy niezbyt wiarygodnej i wybiórczej historiografii - którą w drugiej połowie XIX wieku zaczęła intensywniej wspierać rozwijana obcymi rękami archeologia. Właśnie w tym czasie szczególnie dowartościowano w pierwszej kolejności przejawy tradycji ludowej (wpisującej się w aurę myśli herderowskiej) - i to nie tylko w przejęciu strukturalnych składników pieśni lirycznej przez wysoki obieg literatury, lecz także w potraktowaniu jej jako głównego kwalifikatora tożsamości słowiańskiej, następnie etnonimicznie bułgarskiej, wreszcie bułgarsko-macedońskiej i u progu XX stulecia - czystej macedońskiej. Różnej narodowości zbieracze pieśni przemierzający Macedonię doszukiwali się w nich niejednokrotnie dowodów na archaiczność folkloru bałkańskich Słowian jako całości, których dorobek przenikały cechy

2 J. Хаџиконстантинов-Џинот, Кратово, „Цариградски вестник” 1855, бр. 208 (15 I), cyt. za: Просветителството во Македонија, ред. Г. Сталев, Битола 2008, стр. 232.

3 Por. К. Миладинов, Предговор [w:] Д.К. Миладиновци, Б'лгарски народни песни, Загреб 1861, стр. VII.

${ }^{4}$ Р. Жинзифов, Гусљар в собор, Новобългарска гусла, „Братски труд” 1862, кн. 4, стр. ХІІ. 
transkulturowe stanowiące własność wielu społeczności zamieszkujących ziemie leżące na styku międzyetnicznym, wobec czego dopiero z czasem tytuły zbiorów tych utworów stawały się kością niezgody politycznej z powodu ich jednonarodowych brzmień. Donośna frazeologia ogólnosłowiańska, choć zauważalna już u Hadžikonstantinova-Džinota, zaszczepiana wszak była na tych terenach głównie u Serbów i Bułgarów - i to pośrednio siłami upolitycznionej rosyjskiej etnografii slawistycznej, uznającej tego typu wspólnotowość za swój zasadniczy cel strategiczny. Przynależność materiału twórczości ustnej do takiego czy innego dziedzictwa narodowego określano więc zwykle w zależności od stopnia podatności na ideę unifikacyjną albo też w odpowiedzi na potrzebę terytorialnego „przywrócenia jedności” (w przypadku nauki silnego samodzielnego państwa) lub w końcu wyartykułowania argumentu własnego separatyzmu. Kuzman Šapkarev uzna zatem swą kolekcję pieśni za ogólnonarodową własność ${ }^{5}$ ze względu na szerszą ideę jedności bułgarsko-macedońskiej, którą wówczas wyznawał, ale Stefan Verković chciałby z kolei w swoim zbiorze podobnych utworów widzieć przede wszystkim dowód niezmienności w czasie językowej warstwy zamieszczonych tam tekstów autorstwa używających odrębnej mowy „macedońskich Bułgarów"6. Spójne określanie własnej tradycji przez wcześniej wyemancypowanych wschodnich sąsiadów Macedończyków dokonywało się w czasie, gdy ci ostatni samookreślali się jeszcze nadal w sposób archaiczny jako Słowianie, w późniejszej zaś fazie - jak uważają dziś macedońscy badacze ruchu odrodzeniowego - ,imię bułgarskie” zostało przez nich tylko taktycznie ,przejściowo zapożyczone" w celu pozyskania wsparcia materialnego i politycznego, w rzeczywistości kryjąc już dwa niezależne człony tradycji. Ich prototypy sytuowały się w odrębnych kulturosferach: jedna jeszcze w XIX wieku ożywiała topikę protobułgarską i tracką, druga - aleksandryjską; jedna budowała średniowieczny mit Presławia, druga - państwa Samuela. Oba nurty autoidentyfikacji łączyła postawa antygrecka, tak przejrzyście wyrażona piórem Dimitara Miladinova: „Tukidydes, Eurypides, / I Herodot wraz z Pindarem, / Nieznajomi w rodzie naszym, / Żaden dziadem czy pradziadem"’

Już od czasu słabnięcia Imperium Osmańskiego od końca wieku XVIII wieloźródłowość i archaiczność kilku nakładających się na siebie tradycji w obrębie zatomizowanego terytorium przysparzała kłopotów zewnętrznym obserwatorom ze świata nauki i polityki pragnącym wyjaśnienia konfliktu stron aspirujących do bezpośredniego zwierzchnictwa nad ziemiami macedońskimi. Niezależnie od dezorganizującego życie społeczne oddziaływania kilku równoległych systemów oświaty, w ostatnich dekadach XIX stulecia nasiliła się penetracja kraju przez wysłanników carskiej dyplomacji, którzy zmierzali za pomocą instrumentów mechanicznej analizy statystycznej do zbudowania czytelnego etnopolitycznego obrazu kilku najbardziej wpływowych oraz liczebnie tu dominujących wspólnot

5 Por. К. Шапкарев, Предговор [w:] Сборник от български народни умотворения, ч. 1, София 1891, стр. III.

${ }^{6}$ С. Верковиќ, Предговор [w:] Народне песме македонски Бугара, књ. 1, Београд 1860, стр. XI.

7 Д. Миладинов, Грк и Б’лгарин, „Б’лгарски книжици” 1858, бр. 24, стр. 351. 
chrześcijańskich - i stąd między innymi z poparciem Patriarchatu Konstantynopola skłonni byli uznać formy „tradycyjnego życia” na tych terenach ogólnie za bułgarskie. Co prawda z drugiej strony przypominano, że Macedończycy są „prawdziwymi potomkami” Słowian chrystianizowanych przez Braci Sołuńskich $^{8}$, a Kuzman Šapkarev dodawał, że zamieszkują oni niezmiennie ten sam kraj „od czasów apostolskich”, lecz równocześnie trwale obecne było przekonanie o stałej skłonności tego ludu do samoponiżenia za sprawą obecności kilkusetletniej innowierczej władzy ${ }^{10}$. Przez cały wiek XIX poprzez nieliczne utwory artystyczne i publicystyczne, amatorską twórczość dziejopisarską i teksty folkloru przewija się za to myśl o fundamentalnym znaczeniu dziedzictwa zlikwidowanego w 1767 roku Arcybiskupstwa Ochrydzkiego, chociaż w ich wymowie dostrzegalne są braki w elementarnej edukacji historycznej. Nie dysponowano bowiem dokładnym rozeznaniem w zjawiskach heterogenicznych i umiejętnościami krytycznej chronologizacji przeszłości, w związku z czym na równi z dziejami instytucjonalnej Cerkwi traktowano na przykład dane z przekazów apokryficznych - podobnie jak heroiczny świat macedońskiego antyku poddawano bezkrytycznej slawizacji ${ }^{11}$. Mimo wszystko to właśnie stopniowe oczyszczanie z nalotu fikcji konkretnych tradycji (intersemiotycznych „systemów selektywnych”) zaopatrywało liczne grono etnografów i dziejopisarzy w wymierną wiedzę ludoznawczą, a następnie pozwoliło wyposażyć również wyobraźnię literacką w świadomość tego, co stanowi prawdę historyczną, a co pozostaje w sferze mitu i legendy.

„Rodu własnego starożytności”, jak nazywał kolektywne dziedzictwo jednego i drugiego rodzaju G'org'i Pulevski w swym kompilacyjnym dziele Славјанскомакедонска општа историја (1892), stały się także na progu kolejnego stulecia nieweryfikowalnym symbolicznym punktem odniesienia wszelkich prób słowiańskiej interpretacji genotypu aleksandryjskiego (Isaija Mažovski, Kosta Šahov i inni). Ten wyraźny anachronizm współbrzmiał jednak z nowym tonem kształtującym warstwę ideową licznych tekstów - była nim semantyka „tradycji wolności”, o której jako o ponadpokoleniowej wartości constans w 1905 roku wprost pisał na łamach periodyku „Револуционерен лист” Dimo Hadži Dimov. Plejada legendarnych bohaterów stała się ostatecznie urzędowym składnikiem spersonalizowanej tradycji w systemie świeckiej liturgii późniejszego titowskiego państwa. Misirkov, jako główny intelektualny filar nowoczesnego macedońskiego separatyzmu, wspominał w 1924 roku o „duchowej mocy i wiekowych tradycjach” wspólnoty etnicznej, które uosabiali między innymi „prorocy i wy-

${ }^{8}$ К. Петковиќ, Писмо С. Верковићу [1860] [w:] Документи за българско възраждане, ред. Д. Велева, Т. Вълов, Х. Христов, София 1969, стр. 19.

${ }^{9}$ К. Шапкарев, Българският буквар, ч. 2, Цариград 1868, стр. 95.

${ }_{10}$ Por. Г. Прличев, Автобиографија [1885], Скопје 2004, стр. 40.

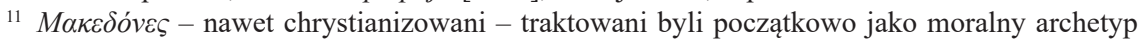
w oporze przeciw Osmanom, do czego argumentacji dostarczały bułgarskie i serbskie aleksandreidy. Podobna topika utrzymana będzie przez G'org'i Pulevskiego, Grigora Prličeva, Rajko Žinzifova, Marko Cepenkova czy Isaiję Mažovskiego; polityczną wykładnię antycznego wątku zmodernizowali następnie Dimitrija Čupovski, Vasil Ivanovski i Nikola Karev. 
raziciele ducha narodowego" święci Kliment i Naum ${ }^{12}$ - za czym stała konieczność afirmacji już istniejących autorytetów (w ich pierwszym szeregu został też ulokowany panbałkański heros epicki królewicz Marko - personifikacja ,macedońskiej muzy" inspirującej wszystkich gęślarzy i śpiewaków Bałkanów do podtrzymywania ciągłości powszechnego ducha pieśni) ${ }^{13}$. W ślad za tym pierwszym macedońskim slawistą wyposażonym w rosyjskie wykształcenie postępował publicysta o częściowo bułgarskojęzycznym dorobku Arseni Jovkov, dla którego jasno już terminologicznie określona tradycja miała uobecniać się w „duszach, sercach i potrzebach" narodu ${ }^{14}$. Tymczasem lata międzywojenne przyniosły nad Wardarem falę serbizacji, której sofijscy urzędnicy próbowali spoza granicy przeciwdziałać na przykład poprzez tajny kolportaż Katechizmu macedońskich Bułgarów. Znalazły się w nim zalecenia kultywowania obyczajów „ojców i dziadów”, zawierania monoetnicznych małżeństw czy używania żeńskich i dziecięcych strojów ludowych ${ }^{15}$; w podobnych wskazówkach dla działających zrzeszeń kobiecych nakazywano podtrzymywać obrzędy kalendarzowe i rodzinne oraz rozpowszechniać wśród dzieci bajki ludowe za pośrednictwem siatek aktywistek - „sióstr”. W dokumentach Wewnętrznej Macedońskiej Organizacji Rewolucyjnej (VMRO) też broniono ,tradycyjnych” obyczajów i kultów przed modyfikacją z zewnątrz (ale tu chodziło zarówno o serbską slavę, jak i bułgarskiego pochodzenia święto Cyryla i Metodego ${ }^{16}$. Krytykowano między innymi na forum międzynarodowym zakaz wyboru imienia dla dziecka spoza oficjalnej listy, a kiedy w 1936 roku funkcjonariusze dyktatury Metaksasa w Grecji zabronili Macedończykom użycia ojczystego języka także w domu i rozpoczęli konfiskatę nagrań ich muzyki ludowej, zwrócono się również przeciwko tym aktom dyskryminacji.

Promieniowanie niektórych genotypów tradycji masowo wykorzystywanych w praktykach końca XIX stulecia osłabło po 1945 roku, gdy w założeniach polityki kulturalnej socjalistycznej republiki skumulowano zmodyfikowane argumenty słowianofilskie z rezultatami ponownej lektury serbskich oraz bułgarskich prac etnograficznych i dogmatami marksistowskich nauk społecznych. Powojenne wymagania polityczne, sytuacja międzynarodowa oraz wyzwanie prestiżu stojące przed najmłodszą literaturą, językiem i kanonem kulturowym Słowiańszczyzny nie pozwoliły na ryzykowny (grożący konfliktem sąsiedzkich nacjonalizmów) powrót do paradygmatu antycznego, dokładniejsze nad nim studia i popularyzację. Antidotum na wszechpanujący słowiański folkloryzm z odcieniami antytureckim i antyfaszystowsko-socjalistycznym (rzecz znamienna, że ostatnimi w kolejności okupantami Macedonii Wardarskiej byli Bułgarzy) z czasem stało się odkrywanie walorów tradycji śródziemnomorskiej, tekstualizującej się - głównie

${ }^{12}$ К. Мисирков, Повеќе Македонц̧и [w:] Собрани дела III, Скопје 2008, стр. 293; Ќ успеат ли?, ibid., стр. 283.

${ }_{13}$ К. Мисирков, Крали Марко, ibid., стр. 234.

${ }_{14}$ А. Јовков, Българският правопис, „Мироглед” 1922, бр. 16, стр. 155.

15 Por. Катехизис македонских болгар [w:] Македония. Сборник документов и материалов, ред. Д. Косев и др., София 1980, стр. 746-751.

16 Por. Из бюллетеня ЦК ВМРО о положении и духе населения в Вардарской и Эгейской Македонии (1926-1927), ibid., стр. 818. 
w poezji od lat sześćdziesiątych - w motywie synkretyzmu dziedzictwa, zwłaszcza dotykalnego w materii pozostałości świata antyku. Miał on jednak nieuchronnie głównie helleńskie nacechowanie, więc musiał (w funkcji symbolicznego „interkontynentu" ${ }^{17}$ czy ,śródziemnomorskiego Hinterland” ${ }^{18}$ ) być zamaskowany aurą skojarzeń ze sferą klimatu i natury, formułując kod estetyczny cywilizacji Mare Internum (i mit Lewantu) jako topikę ,,przerwanej tradycji”, w rzeczywistości wyrażającą stojącą ponad kalendarzami polityki i kultury nadzieję na powrót Macedończyków na egejskie wybrzeża ${ }^{19}$. Nadal uzupełniany przez genotypowe elementy tak zwanej tradycji rewolucyjnej, ten nurt aktualizacji przeszłości musiał początkowo współgrać z całym ekwipunkiem ideologii komunistycznej, którą dodatkowo zabarwiał relatywizmem fakt, że ostatnia wielka martyrologiczna batalia narodu o jej urzeczywistnienie wiązała się z przegraną podczas wojny domowej toczącej się właśnie w Grecji - w latach 1946-1949. Gdy zatem z titowskiego Belgradu płynęły sygnały nawołujące do apologii wszelkich ,postępowych ruchów społecznych", w Skopje internacjonalistyczna teza o samostanowieniu narodów napotkała potężne wsparcie, a ukryta w świadomości głębokiej i literacko nacechowana „tęsknota za Południem" mogła jako zaszyfrowany komunikat co najwyżej zostać odłożona do czasu rozpadu jugosłowiańskiej federacji.

Drugą połowę omawianego stulecia charakteryzuje utrwalanie w narodowej wyobraźni wszystkich pozytywnie waloryzowanych pierwiastków kultury duchowej, myśli politycznej czy imaginarium heroicznego posiadających znamiona lokalnej autonomii - niezależnie od ograniczeń panującego światopoglądu. Dotyczy to dzieła świętych Klimenta i Nauma, monarchii Samuela, ruchu bogomilskiego ${ }^{20} \mathrm{i}$ antyheretyckiej spuścizny prezbitera Kosmy (zaakceptowano nawet pewne zasługi greckiego arcybiskupa Teofilaktesa z Ochrydu czy pochodzącego z Prilepu przeciwnika hesychazmu Gregoriosa Akindinosa); także wielorodnej tradycji całego odrodzenia kulturalnego XIX wieku ${ }^{21}$ oraz wynikającej z niej próby przełożenia programu narodowego na akty polityki praktycznej (philosophia actualis). Sens centralnej figury powszechnego zrywu - powstania ilindenskiego z 1903 roku $^{22}$ - przeniesiono na datę formalnych ,narodzin narodu” u progu epo-

17 Н. Радически, Медитеранските коти на / во македонската поезија [w:] Македонската литература и култура во контекстот на медитеранската културна сфера, ред. М. Ѓурчинов, Скопје 1998, стр. 166.

${ }_{18}$ К. Кулавкова, Припадноста на македонската книжевност на т.н. медитеранска културна сфера, ibid., стр. 244.

19 Jedna z wcześniejszych eseistycznych manifestacji takiej postawy: Б. Ѓузел, Историја и минато, Историјата како маштеа, Скопје 1971, стр. 106-109.

20 Tropy te widoczne są wyraźnie na przykład w prozie Lazo Karovskiego (Климент Охридски. Наум Охридски - 1989), Simona Drakula (Буни - 1979), a przede wszystkim Slavko Janevskiego (wielowarstwowa trylogia Миракули на грозомората - 1984); w poezji upowszechniały się stopniowo w tekstach Ante Popovskiego, Petara Boškovskiego, Liljany Dirjan, Radovana Pavlovskiego, Bogomila G'uzela czy Sande Stojčevskiego.

21 Wiersze poświęcone reprezentantom dziewiętnastowiecznego odrodzenia Konstantinowi Miladinovowi czy Grigorowi Prličevowi ogłaszał już w pierwszej połowie lat pięćdziesiątych Blaže Koneski.

22 Przykładem wykorzystania tej tematyki może być cykl poetycki Илинденски мелодии (1948) Blaže Koneskiego czy wiersze Todora Čalovskiego poświęcone G'org'i Pulevskiemu, Goce Delčevowi oraz Jane Sandanskiemu. 
ki socjalistycznej (1944 - drugi Ilinden), aż wreszcie za zamknięcie wielkiego cyklu historycznego uznano przełomowy rok 1991 - trzeci [i ostatni] Ilinden ${ }^{23}$. Ogólne rozumienie tradycji - ,ustnego przekazu materiału historycznego"24 ulega konkretyzacji jako „narodowe dobro kulturalne stanowiące świadectwo naszej podmiotowości" 25 , czemu towarzyszy ustalenie układu współrzędnych całkowicie nowego fenomenu - macedońskiej tradycji literackiej.

Zdobywa on uprawnienia terminologiczne w studiach literaturoznawczych, tekstach eseistycznych i krytyce, odnosząc się nie tylko do utworów powstałych po II wojnie światowej w wardarskiej części Macedonii. W jego kontekście przypominane są między innymi zagadnienia wspólnej/jednoczesnej przynależności całych fragmentów wcześniejszego dziedzictwa do procesów dziejów piśmiennictwa kilku narodów regionu, asymilacji i modyfikacji bizantyjskiego systemu genologicznego, dowartościowania średniowiecznych lokalnych kompilacji oraz przekładów jako pierwszych symptomów oryginalności, (proto)etnicznej natury „źródłowych" tekstów folkloru, podwójnej klasyfikacji twórców pogranicza językowo-kulturowego bądź posiadających ,transetniczną” świadomość (Grigora Prličeva, Jordana Hadžikonstantinova-Džinota, Nikoli Vapcarova i wielu innych). Nie tylko dochodzi do licznych reedycji dzieł podobnych autorów w zgodzie z normami skodyfikowanego już na oficjalnych zasadach języka, ale i w opisie tendencji artystycznych dochodzi do diachronicznego scalenia poszczególnych niespójnych faz ewolucji literatury (począwszy od problemu długiego średniowiecza), którym nadaje się na przykład standardowe nazewnictwo prądów (typu modernizmu) wbrew ich wtórnemu oraz opóźnionemu występowaniu czy nawet nieobecności w przeszłości (do takiej grupy zabiegów należy koncepcja ,ciągłości nietypowej”) ${ }^{26}$. Na rozmaitość podobnych bałkańskich paradygmatów rozwojowych czasem spogląda się zresztą z porównawczym dystansem, przypominając, że wiele $\mathrm{z}$ nich rodziło się $\mathrm{w}$ warunkach oświeceniowo-romantycznego policentryzmu kulturowego, dla których typowe było uleganie dialogowej wymianie wartości z wielkimi zewnętrznymi centrami ideowymi, rywalizacja etnogenetyczna i odstępstwa od wzorca ,jeden naród - jeden język - jedna tradycja literacka" ${ }^{27}$.

Podstawa ówczesnej twórczej idealizacji i rekonstrukcji przeszłości na bazie nielicznych przed 1945 rokiem tekstów kanonicznych kultury etnicznej tkwiła w dwóch źródłach: romantycznym folklorocentryzmie i historyzmie marksistowskiego podejścia do całej sfery niematerialnej działalności człowieka. W obu przypadkach punkt odniesienia stanowiła struktura społeczna południowosłowiańskich

${ }^{23}$ Termin ten pojawił się już w 1990 roku, antycypując nadchodzące wydarzenia. Por. Чucm македонски збор и во нашите ирковни проповеди, ред. А. Гиревски, Скопје 1995, стр. 298.

24 Речник на македонскиот јазик, т. 3, ред. Б. Конески, Скопје 1966, стр. 392.

25 Македонијо, во срие те носам (red. zbior.), Скопје 1980, стр. 171.

26 Por. К. Кулавкова, Контитуитетот на македонската книжевна историја - некои книжевно-историски и теориско-методолошки соочувања, „Спектар“ 1988, бр. 11, стр. 207-226.

27 Por. И. Доровски, Балканско-медитеранные межлитературные иентризмы [w:] XII Międzynarodowy Kongres Slawistów. Kraków 27 VIII-2 IX 1998. Streszczenia referatów i komunikatów - literaturoznawstwo, folklorystyka, nauka o kulturze, red. L. Suchanek, L. Macheta, Warszawa 1998, s. 63 . 
zbiorowości z dominacją uznawanego za faktyczną reprezentację proletariatu chłopstwa, które w powszechnym odczuciu było tu właściwym podmiotem zmian ustrojowych (lecz zarazem ostoją przezwyciężanego tradycjonalizmu). Podziały na substrat kultury wiejskiej i miejskiej czy obiegu ustnego i pisemnego tekstów miały przy tym znaczenie podstawowe, wyodrębniając pozytywnie nacechowane nośniki wartości prawdziwie ,tradycyjnych”, czyli moralnie nieskażonych i jednocześnie postępowych (wspólnotowo-demokratycznych). Niejednokrotnie te rozróżnienia okazywały się ważniejsze niż choćby opozycje słowiańsko-niesłowiańskie przy opisie poligenezy pieśni ludowej czy symbiotyczna natura obrzędowości ludu otwartego na heterogeniczne wpływy. Świadczy o tym również w literaturoznawstwie i kulturoznawstwie na długo przed 1991 rokiem wskazywana obecność w ustnych narracjach składników twórczo asymilowanych - podań antycznych, greckich legend o świętych, zapożyczeń ze świata tradycji apenińskich (wenecko-włoskich) czy motywów tureckich, albańskich oraz arumuńskich. Niezależnie od tego świat epickich tekstów południowosłowiańskich posiadał własny kanon wspólny i panteon herosów, reaktualizowany jeszcze podczas II wojny światowej w ówczesnych pieśniach bohaterskich, także nie bez udziału innych narodowości. W końcowym rozrachunku kolektywistyczna konwencja ekspresji literatury ustnej stała się głównym wyróżnikiem narracji o pochodzeniu, tworząc zrąb społecznej oraz narodowej więzi. Dla Slavka Janevskiego to сказание од искони ${ }^{28}$ jest równoznaczne $\mathrm{z}$ archaiczną opowieścią etnogenetyczną, której treść z kolei - zdaniem Blaže Koneskiego - zawsze musiała warunkować określona sankcja kolektywu ${ }^{29}$. Ze względu na swój obronno-konserwujący system wartości genotyp ludowy w poetyce ,żywego wspomnienia” przekuwał pamięć historyczną w mity, czemu sprzyjała ,zasada ciągłości przenoszenia motywów jednostkowych lub zbioru idei w czasie"30. W ten sposób przekazywaniu podlegały wiedza o normach gatunkowych tekstów użytkowych, schematy rytmiczno-melodyczne muzyki, komponenty kultury materialnej, normy moralne i prawo zwyczajowe (związane na przykład z tradycją emigracji zarobkowej- печалба) czy symbolika religijno-kultowa - zarówno chrześcijańska, jak i pogańska ${ }^{31}$.

Po roku 1991 tekstotwórczy aspekt sensów tradycji został określony w odpowiedzi na potrzebę homogenizacji całego cywilizacyjnego arche jako bodźca narodo- oraz państwotwórczego, sumy znaczeń powtarzalnych dla syntetycznej (nowo)macedońskiej symbolosfery i także ,punktów zakotwiczenia” działań edukacyjnych. Odtwarzane genotypy były w wielu przypadkach te same, co jeszcze nawet u dziewiętnastowiecznych poprzedników. Dyskurs literacki zwykle wyprzedzały pod tym względem właśnie wypowiedzi obliczone na efekt dydaktycz-

${ }^{28}$ Symboliczny tytuł pierwszego cyklu wierszy w tomie Евангелие по Итар Пејо (1966).

29 Jasno wyraża to stanowisko wstęp do zbioru poetyckiego: Б. Конески, Стари и нови песни, Прилеп 1979.

30 Т. Вражиновски, Народна традииија-религија-култура, Скопје 1999, стр. 7. Reprezentantami tej postawy była w okresie 1945-1991 cała plejada twórców - począwszy od poetów Blaže Koneskiego, Petre Andreevskiego i Sande Stojčevskiego, a skończywszy na prozaikach Stale Popovie, Jordanie Leovie, Živko Čingo, Vase Mančevie czy Dragi Mihajlovskim.

${ }^{31}$ Szersze rozwinięcie tego problemu zob. L. Miodyński, Powroty znaczeń. Aktualizacje tradycji kulturowych w literaturze macedońskiej po 1945 roku, Katowice 1999. 
ny, a prócz (i wśród) nich praktyki dziennikarskie, paranaukowe studia historiograficzne i z zakresu dziejów sztuki, a także daleko idące paralele polityczne z przeszłością w oficjalnych wypowiedziach aktorów życia państwowego ${ }^{32}$. Nie stanowiły w tym przeszkody na przykład takie niewyjaśnione dokładnie kwestie, jak podmiotowość prehistorycznych kultur terytorialnych w Macedonii na tle terenów sąsiednich, stosunek państwowego organizmu Aleksandra Wielkiego do cywilizacji Pajonów (rzekomo bliskich odległemu w czasie słowiańskiemu stylowi życia), relacje pomiędzy wczesnochrześcijańską kulturą grecką i dawnymi sklawiniami, ścisła chronogeografia misji cyrylometodejskiej wśród poszczególnych południowosłowiańskich wspólnot plemiennych, rywalizacja bułgarsko-bizantyjska podczas panowania Samuela na początku XI wieku czy też zakres kulturalnego oddziaływania Serbów w przededniu inwazji tureckiej. Wszystkim niedookreślonym zamierzchłym epizodom historii została przeciwstawiona wielka metafora „wkładu cywilizacyjnego” wieloetnicznego kraju i jego mieszkańców do dziejów powszechnych, obdarzającego dziedziczną mocą zarówno dzisiejszych potomków paleobałkańskich Pelazgów (uznawanych wręcz za praojców ludzkości), jak i spadkobierców chwały epok homeryckiej i fenickiej (w licznych dziełach Taško Belčeva) oraz oczywiście Macedończyków antycznych - ocalających ideę terytorialnej monarchii rzekomo bezpośrednio z ginącej Atlantydy (Jozo Boškovski Jon) ${ }^{33}$.

Spoiwo ideowe stanowi w takich diagnozach zawsze, jak utrzymuje w swych pracach Stefan Vlahov-Micov, ponadczasowe zjawisko macedońskiego kosmopolityzmu ${ }^{34}$. Rozmaite mistyfikacje i pozorne podobieństwa służą, tak jak sto lat wcześniej G’org’i Pulevskiemu szukającemu dowodów ciągłości słowiańskiego osadnictwa na ojczystych ziemiach ${ }^{35}$, odnajdywaniu nieprzerwanej tradycji ,macedońskiego ducha", który w każdej nowo odkrytej sensacji archeologiczno-

32 Między innymi pierwszy prezydent republiki Kiro Gligorov skonstatował, że jego naród ,,za pośrednictwem ikon, fresków i snycerstwa wypełnił w kulturze europejskiej czarną dziurę między schyłkiem Bizancjum i zachodnim renesansem”. К. Глигоров, Афирмација на зборот и неговата одговорност, „Современост“ 1992, бр. 1-4, стр. 19.

33 Głównie chodziło o wykazanie znaczenia dla wartości cywilizacji helleńskiej formacji aleksandryjskiej - przechowującej pelazgijski ,„prabałkański gen” oraz zasilanej pajońską walecznością i wnoszącej je do młodszego żywiołu greckich Dorów. Takie samo znaczenie miały rozważania o tożsamości homerowych Wenetów, staromacedońskim „transhistorycznym kodzie językowym” (Aristotel Temtov, Tome Baševski) czy ,alternatywnym Olimpie” (masywach Pelister względnie Pirin - Slobodan Bogoevski) bądź arenie wojny trojańskiej w okolicach Bitoli (miejsca pochodzenia Homera - Risto Ivanovski). Nieco mniej sensacyjne prace historyczne publikowali Angelina Markus, Vasil Tupurkovski czy Lidija Slaveska. W tekstach folkloru doszukiwano się pierwiastków antycznych (motywów lwa, filozofa lub faraona, transmutacji mitu o Herkulesie w postaci królewicza Marka). Na temat pierwszych prozatorskich adaptacji motywu Aleksandra w omawianym okresie por. L. MorozGrzelak, Aleksander Wielki a macedońska idea narodowa, Warszawa 2004.

34 Por. zwłaszcza С. Влахов-Мицов, Филозофскиот клуч за македонскиот идентитет, Скопје 2008.

35 Pulevski przytaczał w związku z tym znany z przekładów tzw. rękopisu Metza czy wersji Pseudo-Kallistenesa Testament Aleksandra. Po 1991 roku Aleksandar Donski w szeregu książek i inni „nieprawomyślni” autorzy powątpiewali natomiast w ogóle w obecność słowiańskiej „,północnej krwi” u dzisiejszych Macedończyków. 
-kronikarskiej urzeczywistniałby ideę sztafety pokoleń. W szczególności continuum esencji języka oraz wizji państwowo-społecznej i religijnej podlega tutaj bezwarunkowej akceptacji - w obrazach odwiecznego antagonizmu macedońskiego genu względem Achajów i Ilirów (czyli obecnych żywiołów greckiego i albańskiego), a nawet w przejęciu zasad mitologicznej kosmogonii z panteonu Hiperborejczyków ${ }^{36}$. Dziedzictwo takie w rzeczywistości okazuje się syntezą wielu innych jeszcze form emanacji kulturowej doskonałości: tradycji orfickiej, idei ekumeny o genezie arystotelesowsko-aleksandryjskiej (motyw racjonalnej europeizacji Orientu przez wielkich przodków), formacji cyrylo-metodejskiej z przejętą przez nią ,,poliglotyczną tożsamością”. Prawo przeniesienia własności migrujących segmentów cywilizacyjnych powinno też w myśl takiej logiki obejmować plejadę antycznych umysłów filozoficznych (Arystotelesa, Filokratesa, Pyrrona, Ksenokratesa) połączonych wspólnym szyldem filomacedonizmu ${ }^{37}$.

Nie można zapominać o młodszym genotypie „tradycji duchowej”, za którym kryje się przede wszystkim czynnik prawosławia, także w aspekcie instytucjonalnym - wczesnośredniowiecznego Arcybiskupstwa Ochrydzkiego (skasowanego w 1767 roku, a odnowionego jako autokefaliczna Cerkiew po dwustu latach) uznawanego za niezależny narodowy Kościół wraz z całą otoczką cerkiewnosłowiańskiej kultury - sprzężonej dodatkowo z nowotestamentową tradycją dzieła świętych misjonarzy Macedonii Pawła i Andrzeja (postaci obecnych w folklorze), a prócz tego wskazujących na to terytorium przekazów Starego Testamentu $^{38}$. Zetnizowane motywy biblijne (jedna z popularnych matryc poetyckich od końca XX wieku) ${ }^{39}$ nawiązują do pierwotnych źródeł często w sposób instrumentalny zwłaszcza wtedy, gdy tle pojawia się nierozwiązana do dziś sprawa oficjalnego zewnętrznego uznania odrębności tej Cerkwi - podobnie jak w XIX stuleciu z ożywieniem przystąpiono do podkreślania własnych korzeni życia religijnego bezpośrednio po utworzeniu Egzarchatu Bułgarskiego (1870). Samemu zaś Ochrydowi, w myśl jednej z dawnych jeszcze (i raczej zarzuconych) teorii będącemu siedzibą przedsłowiańskiego arcybiskupstwa Justiniana Prima, przypisywano gdzieniegdzie bezkrytycznie w dalszym ciągu tradycję Pierwszej Justyniany (w innym nieco kontekście ten wątek podejmuje prozaik Danilo Ko-

36 Por. А. Шкокљев, С. Николовски, Придонесот на Македонија во светската цุивилизација, Скопје 2004.

37 Por. К. Темков, Филозофските идеи во Македонија [w:] Содржински и методолошки прашања во истражувањето на историјата на културата на Македонија, ред. Г. Старделов, Скопје 1995, стр. 217-220.

38 Konotacje te sprzyjają uprawdopodobnieniu synkretyczno-interaktywnej teorii etnosu poszukującej solidnego przedsłowiańskiego substratu i obejmują między innymi takie,,świadectwa tożsamości” jak zapisy w protologii Księgi Rodzaju (tzw. tablicy narodów), I Księdze Machabejskiej, Księdze Daniela, Księdze Estery; ponadto w Nowym Testamencie - Dziejach Apostolskich czy Listach św. Pawła. Ich obecność ma poprzez bogatą egzemplifikację pokazać głównie, że wspominane w kanonicznych tekstach judaistycznych i chrześcijańskich państwo oraz etnos posiadały w czasach biblijnych swe niezależne od innych terytorium i nazwę. Por. Ѓ. Поп-Атанасов, Библијата за Македонија и Македонц̧ите, Скопје 1995; А. Донски, Исус Христос и Македоничите, Штип 2000; niemało jest również utworów literackich inspirowanych wskazanymi motywami.

39 Jednym z prekursorów w tym zakresie był przed 1991 rokiem poeta Ante Popovski. 
cevski w książce Јустинијана, градот кој го нема - 1999) ${ }^{40}$. Całokształt zaś lokalnej tożsamości religijnej teolog Stefan Sandžakoski określa w perspektywie zespolenia pierwiastków protobizantyjskich z biblijno-żydowsko-hellenistycznymi z nawarstwieniem rzymskim, gdzie za elementy łączące uznaje się greckie rozumienie misterium, łaciński ład organizacyjny i żydowskie idee historyzmu oraz mesjanizmu $^{41}$. Niezależnie od ciężaru gatunkowego tej tradycji niezmiennie istotnym proto- $\mathrm{i}$ archetypem pamięci kolektywnej oraz symboliki narodowej pozostaje teżjednak folklor, kodyfikujący dane tej pamięci na poziomie etosu i logosu, w sposób naturalny albo potencjalnie sterowany. Druga z tych sytuacji zachodzi wówczas, gdy na przykład pod presją „,europejskiego antytradycjonalizmu” wkraczającego pod maską kultury masowej można jeszcze dzięki niemu przywrócić autentyczność ustnej tradycji narracyjnej w celu ocalenia własnej wyjątkowości ${ }^{42}$; podobnie motywowano możliwość odnawiania przez wypowiedzi neofolklorystyczne różnych artefaktów etnograficznych z czasów Macedonii antycznej ${ }^{43}$.

Zgodnie z zasadą funkcjonalnej rewaloryzacji kluczowych kompleksów symbolicznych przeorientowano, najpierw w tekstach naukowych, ocenę tradycji herezji bogomilskiej, w której prócz dominanty społecznej i antyklerykalnej zaczęto dostrzegać głębię doświadczenia religijnego oraz kulturowego. Podobnie stało się ze zmianą aksjologicznego stanowiska wobec - materialnej i niematerialnej - tradycji osmańskiej, okazującej się zjawiskiem znacznie bardziej złożonym niż jej dotychczasowy negatywny stereotyp (pokrewny proces miał też miejsce w Bułgarii i szczególnie w Bośni). Macedońskie etnikum uczyniono przedmiotem analizy już nie tylko w duchu marksistowskiej etnokulturowej wykładni narodu, lecz sięgnięto w niej między innymi do klasycznych dzieł antropologii kultury czy tez chrześcijańskiej historiozofii - powracając przy okazji do rodzimych źródeł historiografii klasztornej i żywotopisarstwa, bułgarskich lub greckich traktatów historycznych czy odkrywanych po dziesięcioleciach rosyjskojęzycznych studiów bałkanistycznych. Centralne narodowe instytuty naukowe (historii, literatury, języka, folkloru oraz kultury starosłowiańskiej) przejęły w nowych warunkach odpowiedzialność za koordynację badań wolnej od obcych roszczeń tradycji kulturowej. Jest ona dla niektórych autorów bytem niejednokrotnie metafizycznym, jak dla filozofa Georgi Stardelova uważającego, że związana z nią „metafizyka ziemi” zakłada ciągły hymniczny dialog

40 Tutejsze studia nad tym zagadnieniem starają się wyeksponować prestiżarcybiskupstwa z początku VI wieku w świecie chrześcijańskim i jego przypisanie do ziem macedońskich (obecnie najczęściej do Skopje ze względu na miejsce urodzenia wybitnego imperatora), jak również dziedziczność praw do tytulatury związanej z owym ośrodkiem - dążącym do niezależności od zwierzchnictwa salonickiego czy konstantynopolitańskiego. Epizod historyczny dotyczący autonomicznego chrześcijańskiego centrum naświetlili w swych separatystycznych argumentacjach narodowych na początku XX wieku Krste Misirkov i Dimitrija Čupovski.

41 Por. С. Санџакоски, Пролегомена за истражувањето на православната византискословенска култура на Македонија [w:] Содржински..., стр. 76.

42 Por. tezy zawarte w książce: Е. Лафазановски, Антрополошки дијалози, Скопје 2002.

43 Por. А. Донски, Античко-македонското наследство во денешната македонска нација, Штип 2002. Ten sam rodzaj tekstów umożliwia też połączenie wątków archaicznych z nostalgią po minionej Jugosławii. Zob. Б. Саркањац, Македонски катахрезис, Скопје 2001. 
z długim łańcuchem przodków (personalizacji wzniosłych czynów) - toczący się w rytmie epickiej pieśni jako,,interpenetracja” świata jednostki oraz symboli narodowych. W obrębie takiego wielogłosu umiejscowione są zarówno patriotyczne utwory beletrystyczne, jak i glosy dopisywane do naukowych ustaleń, teksty nowego folkloru oraz tradycje dopiero dowartościowywane (niczym mieszczańska, której nie zdążyło ostatecznie uformować dziewiętnastowieczne „niedokończone odrodzenie" i dodatkowo zahamowała plebejska monokultura komunistyczna) ${ }^{44}$.

Naród wyrosły z nieodległej w czasie regionalnej wspólnoty, której krąg wyobrażeń kształtowała ludowa wizja przeszłości i wielowyznaniowe realia jest wobec tego dziedzicem hybrydycznych i synkretycznych form kulturowych kreowanych przez zbiorowości ,wchodzące w niemiłosierną konkurencję, lecz tworzące wspólne obrazy mityczne i tradycje"45. Wielokulturowy tekst z nimi związany pomagają zatem deszyfrować najrozmaitsze dostępne w obfitości „paleografie, archeologie, teologie i mitologie, pieśni i tańce, sztuki i filozofie, języki i zwyczaje, gramatyki i retoryki"46. W praktyce stosunek do nich był jednak zróżnicowany zależnie od miejsca i czasu ich aktualizacji. Na przykład składniki tradycji państwowej dotyczącej dawnej monarchii Samuela podlegały innej symbolizacji przed utworzeniem bułgarskiego egzarchatu widzącego w niej czynnik własnego dziedzictwa, a inaczej po roku 1870. Odmienne oceny dotyczyły charakteru tradycji pieśni ludowej przed wydaniem fundamentalnego zbioru braci Miladinovów (1861) oraz po tym fakcie czy także po przesunięciu granic państwowych w 1913 roku (różnice w interpretacji dzieliły też już wtedy znacznie Macedończyków i Bułgarów). Rozmaicie rozumiano tradycję patriarchalną w homiletyce wczesnego oświecenia, w świeckim jego nurcie oraz w retoryce budzicieli świadomości narodowej okresu Ilindenu. Tradycję antyczną w inny sposób postrzegano, gdy dojrzewała filohelleńska Megali Idea (obsesja archeolatrii objęła wówczas także ziemie egejskie zamieszkałe przez Słowian), a w inny tradycję helleńską w sensie szerokim widzieli autorzy ochrydzcy czy całkiem odmiennie emigranci w Sofii (лозари); kiedy ostatecznie ostatnie z nich przekształciły się po rozpadzie drugiej Jugosławii w figury tradycji śródziemnomorskiej, powstała na ich podstawie w znacznym stopniu przebudowana semiosfera. Tekstotwórczy potencjał tych i innych wątków kulturowych zmieniał swoją moc, począwszy od kultu objawionego Pisma i hierarchii duchowych Ojców oraz imperatywu poznania i propagowania rodowodu ludu w ideologii oświeceniowo-romantycznej. W następnej kolejności genotypy tradycji wywołały rezonans u twórców koncepcji etnopolitycznego, językowego oraz historiograficznego separatyzmu, kiedy w warunkach „rywalizacji o tożsamość” odbywającej się na całym wyzwolonym spod tureckiego panowania Półwyspie rozpoczęło się ich nowe życie. Wówczas też zadomowiły się na trwałe w narodowym imaginarium, które z końcem tysiąclecia w zhomogenizowanej rzeczywistości trzech systemów kulturowych (tradycjonalizmu,

44 Por. Т. Османли, Граѓански простор, Скопје 2011, стр. 12.

45 И. Доровски, За методологијата на проучувањето на Балканот и Медитеранот [w:] Македонската литература и култура во контекстот..., стр. 131.

46 Г. Старделов, Балканска естетика една друга естетика, Скопје 2004, стр. 72. 
nowoczesności i postmodernizmu ${ }^{47}$ intensywnie zaczęło zasilać sferę literatury. Skutkiem takiej zdeterminowanej przez ciśnienie zmian politycznych nowelizacji i reinterpretacji starych wzorców stało się pewne zahamowanie procesów modernizacyjnych (rozumianych według kryteriów zachodnich jako racjonalizacja i technicyzacja praktyk społeczno-kulturowych), chociaż z drugiej strony dzięki pozytywnej fascynacji historią stworzony został dla zjawisk heterogenicznych obecnych w rozpatrywanych tu tradycjach szeroki margines tolerancji.

\section{Bibliografia}

Башевски П., Коренот нам, Маглите на Кајмакчалан, Скопје 1995, стр. 44.

Верковиќ С., Предговор [w:] Народне песме македонски Бугара, књ. 1, Београд 1860, стр. I-XIX.

Влахов-Мицов С., Филозофскиот клуч за македонскиот идентитет, Скопје 2008.

Вражиновски Т., Народна традииија - религија - култура, Скопје 1999.

Гелевски Н., Македонија помеѓу традииионализмот, модернизмот и мултикултурализмот, „Културен живот” 2000, бр. 3, стр. 5-9.

Глигоров К., Афирмаиија на зборот и неговата одговорност, „Современост” 1992, бр. 1-4, стр. 18-24.

Донски А., Античко-македонското наследство во денешната македонска наиија, Штип 2002.

Донски А., Исус Христос и Македонщите, Штип 2000.

Доровски И., Балканско-медитеранные межлитературные иентризмы [w:] XII Międzynarodowy Kongres Slawistów. Kraków 27 VIII - 2 IX 1998. Streszczenia referatów i komunikatów - literaturoznawstwo, folklorystyka, nauka o kulturze, red. L. Suchanek, L. Macheta, Warszawa 1998.

Доровски И., За методологијата на проучувањето на Балканот и Медитеранот [w:] Македонскаталитератураикултура во контекстотнамедитеранската културна сфера, ред. М. Гуурчинов, Скопје 1998, стр. 119-132.

Ѓузел Б., Историја и минато, Историјата како маштеа, Скопје 1971, стр. 106109.

Жинзифов Р., Гусљљар в собор, Новобългарска гусла, „Братски труд” 1862, кн. 4 , стр. VIII-XX.

Из бюллетеня ЦК ВМРО о положении и духе населения в Вардарской и Эгейской Македонии (1926-1927) [w:] Македония. Сборник документов и материалов, ред. Д. Косев и др., София 1980, стр. 808-820.

Јовков А., Българският правопис, „Мироглед” 1922, бр. 16, стр. 153-158.

Катехизис македонских болгар [w:] Македония. Сборник документов и материалов, ред. Д. Косев и др., София 1980, стр. 746-751.

Лафазановски Е., Антрополошки дијалози, Скопје 2002.

Македонијо, во срие те носам [red. zbior.], Скопје 1980.

Миладинов Д., Грк и Б’лгарин, „Б’лгарски книжици” 1858, бр. 24, стр. 350-351.

47 Por. Н. Гелевски, Македонија помеѓ т традиционализмот, модернизмот и мултикултурализмот, „Културен живот” 2000, бр. 3, стр. 5-9. 
Миладинов К., Предговор [w:] Д.К. Миладиновци, Б'лгарски народни песни, Загреб 1861, стр. III-VIII.

Miodyński L., Powroty znaczeń. Aktualizacje tradycji kulturowych w literaturze macedońskiej po 1945 roku, Katowice 1999.

Мисирков К., Крали Марко [w:] Собрани дела III, Скопје 2008, стр. 231-234.

Мисирков К., Повеќе Македони̧и [w:] Собрани дела III, Скопје 2008, стр. 290294.

Мисирков К., Kе успеат ли? [w:] Собрани дела III, Скопје 2008, стр. 281-284.

Moroz-Grzelak L., Aleksander Wielki a macedońska idea narodowa, Warszawa 2004.

Османли Т., Граѓански простор, Скопје 2011.

Петковиќ К., Писмо С. Верковићу [1860] [w:] Документи за българско възраждане, ред. Д. Велева, Т. Вълов, Х. Христов, София 1969, стр. 19.

Поп-Атанасов Ѓ., Библијата за Македонија и Македонците, Скопје 1995.

Прличев Г., Автобиографија, Скопје 2004.

Радически Н., Медитеранските коти на / во македонската поезија [w:] Македонската литература и култура во контекстот на медитеранската културна сфера, ред. М. Ѓурчинов, Скопје 1998, стр. 163-172.

Речник на македонскиот јазик, т. 3, ред. Б. Конески, Скопје 1966.

Санџакоски С., Пролегомена за истражувањето на православната византиско-словенска култура на Македонија [w:] Содржински и методолошки прашања во истражувањето на историјата на културата на Македонија, red. Г. Старделов, Скопје 1995, стр. 73-82.

Саркањац Б., Македонски катахрезис, Скопје 2001.

Старделов Г., Балканска естетика една друга естетика, Скопје 2004.

Темков К., Филозофските идеи во Македонија [w:] Содржински и методолошки прашања во истражувањето на историјата на културата на Македонија, ред. Г. Старделов, Скопје 1995, стр. 217-220.

Кулавкова К., Контитуитетот на македонската книжевна историја - некои книжевно-историски и теориско-методолошки соочувања, „Спектар” 1988, бр. 11, стр. 207-226.

Кулавкова К., Припадноста на македонската книжевност на т.н. медитеранска културна сфера [w:] Македонската литература и култура во контекстот на медитеранската културна сфера, ред. М. Гурчинов, Скопје 1998 , стр. 237-258.

Хаџиконстантинов-Џинот Ј., Кратово, „Цариградски вестник” 1855, бр. 208 (15 I), cyt. za: Просветителството во Македонија, ред. Г. Сталев, Битола 2008, стр. 229-232.

Чист македонски збор и во нашите ирковни проповеди, ред. А. Гиревски, Скопје 1995.

Шапкарев К., Българският буквар, ч. 2, Цариград 1868.

Шапкарев К., Предговор [w:] Сборник от български народни умотворения, ч. 1, София 1891, стр. I-XXV.

Шкокљев А., Николовски С., Придонесот на Македонија во светската ичивилизација, Скопје 2004. 